[Vol.109:378

\title{
NOTES
}

\section{THE CEMETERY LOT: RIGHTS AND RESTRICTIONS}

"There is nothing certain save Death and Taxes," as the old saw goes. But while lawyers are ever conscious of laws on taxation, they regularly ignore laws pertaining to death-except, of course, those rules dealing with the disposition of decedents' estates. However, questions of the right to control burial, the right to cremate, the right to be buried in a particular cemetery lot, and survivors' rights in the lot often cause bitter controversy between children and a surviving spouse ${ }^{1}$ or between lotowner and cemetery. Such situations often lead to litigation which could have been avoided by an awareness of possible problems and by proper planning. This Note will examine the rights of individuals in individual or family cemetery lots. ${ }^{2}$

At the outset it must be emphasized that a cemetery lot is treated for most purposes as being unlike any other piece of real or personal property. ${ }^{3}$ The custom of setting aside places of burial has a long history. ${ }^{4}$ From the pyramids and cities of the dead of ancient Egypt, through the churchyards of England, ${ }^{5}$ to the modern memorial park, civilized peoples have treated places for the burial of the dead as deserving special protection. This unique treatment results from the traditional absence of commercialism in

1 Very frequently such controversies arise when there has been a second marriage following divorce or death of the first spouse; the children of the first spouse and those of the second spouse are often in disagreement. See Cowan, Report of Idea Exchange Roundtable on Tax Problems \& Corporate Structure, in 1956-1957 CEMETERY YEARBOOK 142, 143. These problems also arise between children when there is no surviving spouse or after the surviving spouse's interest has been determined. See Persinger v. Persinger, 39 Ohio Op. 315, 86 N.E.2d 335 (C.P. 1949).

2 For a discussion of other areas, such as control of the burial, see JACKson, THE Law of Cadavers 41 (2d ed. 1950); Street, Mortuary Jurisprudence 100 (1948). Municipally operated cemeteries and cemetery districts are generally regulated by statute. Their problems are generally similar to those of other cemeteries except where the statute imposes special difficulties. For one such exception, see note 98 infra. This Note will not treat questions of rights in nonprofit lotholder-owned cemeteries, nor special problems of family or religious cemeteries; it will, however, discuss religious restrictions generally.

3 E.g., Sams v. Sams, 242 Ala. 240, 243, 5 So. $2 d$ 774, 776 (1942); Kerlin v. Ramage, 200 Ala. 428, 76 So. 360 (1917); Locke v. Lester, 78 So. $2 d$ 14 (La. Ct. App. 1955); Abell v. Proprietors of Green Mount Cemetery, 189 Md. 363, 56 A.2d 24 (1947) ; Abrams v. Lakewood Park Cemetery Ass'n, 355 Mo. 313, 196 S.W.2d 278 (1946), modified sib nom. Abrams v. Scott, 357 Mo. 937, 196 S.W.2d 278 (1948); Hammerstein v. Woodlawn Cemetery, 21 Misc. 2d 42, 194 N.Y.S.2d 385 (Sup. Ct. 1960); Persinger v. Persinger, 39 Ohio Op. 315, 86 N.E.2d 335, 336 (C.P. 1949); Lanford v. West Oakwood Cemetery Addition, Inc., 223 S.C. 350, 75 S.E.2d 865 (1953).

4 JACKSON, op. cit. supra note 2 , at 6-7, 10-13. Acre"

5 JACKson, op. cit. supra note 2, at 13 . Such grounds have been called "God's 
matters involving such property ${ }^{6}$ and from the extensive ecclesiastical control over burial matters and concomitant clerical discouragement of secular intervention. ${ }^{7}$ Concern for the well-being of the family as a unit also has been a significant factor in inducing courts and legislatures to modify or reverse normal property rules and concepts. ${ }^{8}$ It is this combination of tradition, sentiment, family well-being, and religion which leads to the peculiarities of cemetery law.

\section{Nature and Extent of the Interest Purchased}

One peculiarity of cemetery law concerns the very nature of the right which the purchaser of a cemetery lot acquires. Although the interest taken is usually described as one in real estate, ${ }^{9}$ at times the desire to prevent speculation has encouraged courts to treat a cemetery lot deed as a "security" and on that basis to hold lot salesmen in violation of "blue sky" statutes.10 However, the treatment of a sale of a cemetery lot as anything other than a transaction in realty has rarely arisen except in this context of regulation of cemetery lot salesmen. ${ }^{11}$ This view is reinforced by decisions holding that rights in cemetery lots pass directly to the heirs as real estate rather than becoming a subject of administration, ${ }^{12}$ that a property right may be acquired by adverse possession, ${ }^{13}$ that conveyances are subject to

6 Persinger v. Persinger, 39 Ohio Op. 315, 86 N.E.2d 335 (C.P. 1949); cf. JAckson, op. cit. supra note 2 , at 13 . Courts have noted that cemetery lots are not treated as items of commerce. Abell v. Proprietors of Green Mount Cemetery, 189 Md. 363, 56 A.2d 24 (1947). Nor are they a subject for barter and sale. Fraser v. Lee, 8 Ohio App. 235, 245 (1917). Where such plots have become items of commerce, the court points out that a different rule prevails. Abell v. Proprietors of Green Mount Cemetery, supra; see notes 117-21 infra and accompanying text. Nor have courts ignored the fact that individuals do not treat such property as an ordinary asset. Petition of Waldron, 26 R.I. 84, 58 At1. 453 (1904).

7 JAckson, op. cit. supra note 2 , at 20-25.

8 See the discussions of alienability at notes 140-47 infra and accompanying text, of religious restrictions at notes 87-99 inf $r a$ and accompanying text, and of the rules of descent at notes 127-36 infra and accompanying text.

- Billings v. Paine, 319 S.W.2d 653 (Mo. 1959) ; JACKSon, op. cit. supra note 2, at 362. But see Sams v. Sams, 242 Ala. 240, 5 So. $2 d 774$ (1942). A regular real estate deed need not be used to convey an interest in a cemetery lot. Fraser v. Lee, 8 Ohio App. 235, 240 (1917).

10 Holloway v. Thompson, 112 Ind. App. 229, 42 N.E.2d 421 (1942); State v. Lorentz, 221 Minn. 366, 22 N.W.2d 313 (1946); In the Matter of Walstein, 160 Misc. 763, 291 N.Y. Supp. 697 (Sup. Ct. 1936). But see Memorial Gardens of the Valley, Inc. v. Love, 5 Utah $2 \mathrm{~d} 270,300$ P.2d 628 (1956).

11 But see Sams v. Sams, 242 Ala. 240, 5 So. $2 d 774$ (1942) (not "other real estate" within meaning of divorce statute).

12 In the Matter of the Estate of Rosen, 173 Misc. 433, 17 N.Y.S.2d 794 (Surr. Ct. 1940) (based on New York statutes). This is the general rule. See Cemetery Legal Compass, July 1940, p. 212.

13 C. L. Gray Lumber Co. v. Pickard, 220 Miss. 419, 71 So. 2d 211 (1954); Billings v. Paine, 319 S.W.2d 653 (Mo. 1959); Corkill v. Calvary Cemetery Ass'n, 29 Ohio Op. 554 (C.P. 1944); Sherrard v. Henry, 88 W. Va. 315, 106 S.E. 705 (1921). However, the property right which may be acquired by adverse possession rises no higher than an easement. Brown v. Hill, 284 I11. 286, 293, 119 N.E. 977, 980 (1918). 
the statute of frauds, ${ }^{14}$ and that lot salesmen are required to be registered under state real estate salesmen acts. ${ }^{15}$

Once having determined that a lot represents a right in realty, most courts have held that a deed which grants only the right of sepulture creates an easement or irrevocable license to use the ground for burial so long as the cemetery remains a cemetery. ${ }^{16}$ A few jurisdictions have described the right as a qualified fee. ${ }^{17}$ However, in the interest of clarity, it would be helpful to recognize the grant of a right of sepulture as sui generis. This is the view adhered to by one jurisdiction 18 and advocated by a leading textwriter. ${ }^{19}$ Inasmuch as courts rarely reach divergent results merely on the basis of the label attached to the interest, ${ }^{20}$ it is more realistic to acknowledge the unique way in which cemetery lots are treated; otherwise the true issues are confused and concealed by arbitrarily assigning real property tags which have the characteristics desired for the resolution of a particular case consonant with an appropriate though unenunciated theory of cemetery law.

While the courts may have had difficulty in determining the interest which a grant of sepulture creates, they have been extremely quick to construe deeds which purport to convey a fee simple ${ }^{21}$ as granting an

14 Cf. Kesselman v. Goldsten, 148 Neb. 452, 27 N.W.2d 692 (1947).

15 See generally Cemetery Legal Compass, Nov. 1936, pp. 17-19.

16 E.g., McWhirter v. Newell, 200 I11. 583, 66 N.E. 345 (1903); Antoniewicz v. Del Prete, 166 N.E.2d 706 (Mass. 1960); Persinger v. Persinger, 39 Ohio Op. 315, 86 N.E.2d 335 (C.P. 1949) ; Fraser v. Lee, 8 Ohio App. 235 (1917). A few courts have described the interest as being an easement only. Turkowska v. Dielendick, 321 Mass. 754, 76 N.E.2d 556 (1947); cf. Brown v. Hill, 284 I11. 286, 119 N.E. 977 (1918) ; Haas v. Gahlinger, 248 S.W.2d 349 (Ky. Ct. App. 1952); Hammerstein v. Woodlawn Cemetery, 21 Misc. 2d 42, 194 N.Y.S.2d 385 (Sup. Ct. 1960). Others have characterized the interest as an irrevocable license alone. Gowen v. Bessey, 94 Me. 114, 116, 46 At1. 792, 793 (1900); Page v. Symonds, 63 N.H. 17, 19 (1883); Ez Achaim Soc'y, Inc. v. Cohen, 15 Misc. 2d 540, 181 N.Y.S.2d 717 (Sup. Ct. 1958); Kincaid's Appeal, $66 \mathrm{~Pa}$. 411, 421 (1870); Oak Park Cemetery v. Donaldson, 148 S.W.2d 994, 998 (Tex. Ct. Civ. App. 1940). The latter description seems to be an analogy to the pewholder's right. See JAckson, op. cit. supra note 2, at 353; Schley, Property in Church-Pezes, Market-Stalls and Lots in Cemeteries (pts. 1-2), 28 U. PA. L. REv. 1, 65 (1880). In Turkowska v. Dielendick, supra, the court noted that if the interest is an easement, an action in trespass will lie, while if the interest is a license, such an action will not lie. See also Oak Park Cemetery v. Donaldson, supra. For a discussion of actions of trespass, see notes 101-08 infra and accompanying text.

17 Silverwood v. Latrobe, $68 \mathrm{Md}$. 620, 13 Atl. 161 (1888). See Commissioner v. Cedar Park Cemetery Ass'n, 183 F.2d 553 (7th Cir. 1950), where the Commissioner attempted to claim an indefinite rental. See also Corkill v. Calvary Cemetery Ass'n, 29 Ohio Op. 554 (C.P. 1944). This concept of rental is an ancient one: "Centuries ago in some portions of the world it seemed to be the custom to bury bodies in public cemeteries with an annual charge for rental for the space occupied by the dead. Failure to pay the annual rental resulted in disinterment of the bones which were cast upon a public dump provided for such purpose." Id. at 556. Even today tombs may be rented in sections of Louisiana.

18 Schaefer v. West Lawn Memorial Cemetery, 352 P.2d 744 (Ore. 1960); Mansker v. Astoria, 100 Ore. 435, 198 Pac. 199 (1921).

19 JACKson, op. cit. supra note 2, at 360-61.

20 But see note 16 supra and accompanying text.

21 In most cases, however, either the language of the instrument or surrounding circumstances give at least some indication that the grant conveyed a lot in a cemetery and not "ordinary" realty. E.g., Love v. Robinson, $219 \mathrm{~Pa}$. 469, 68 Atl. 1033 (1908) (taken subject to rules and regulations); cf. Kansas City v. Scarritt, 169 Mo. 471, 69 S.W. 283 (1902). 
easement or a license only. ${ }^{22}$ As one leading commentator, Jackson, has said in justification of this rule: "In states where the intention is to have cemeteries owned by a corporation organized to give to the lot owners permanent management and care, there must be a right of regulation in the corporation. In such cases every sound legal and practical reason justifies retention of the fee in the association so that it may exercise control." 23 However, this explanation does not fully support the judicial practice of removing one tag (fee simple) with a well-defined meaning in other real property areas, and substituting another (easement or license) whose general property attributes more nearly give the desired answer in a particular case. In ordinary circumstances, Jackson's view may be adequate justification for the harsh step of converting a fee into a lesser property right in that the cemetery must have the power to regulate the grounds effectively. ${ }^{24}$ But this propensity to change labels has undesirable consequences when different problems arise. Consider the position of a group of contiguous lotowners, having been granted the ground in fee, who find the cemetery poorly maintained due to a lack of administration. They desire to withdraw in order to organize separately. As easement holders or licensees they are precluded from doing so, even though the reason for originally reducing their interest is inapplicable.

Even more significant consequences of reducing a fee simple title to a mere easement or license are found in the allocation of rights upon the abandonment of the cemetery. ${ }^{25}$ In general, the interest of the individual

22 E.g., Kansas City v. Scarritt, supra note 21 ; Pitcairn v. Homewood Cemetery, $229 \mathrm{~Pa} .18,77$ Atl. 1105 (1910). However, in dealing with cemeteries, possession of the fee without a right of sepulture is, for most purposes, valueless. Commissioner v. Cedar Park Cemetery Ass'n, 183 F.2d 553 (7th Cir. 1950). But see Haas v. Gahlinger, 248 S.W.2d 349 (Ky. Ct. App. 1952), where the court pointed out that a conveyance in fee does not become an easement if later used for burial.

23 JACKSON, op. cit. supra note 2 , at 359.

24 See notes 29-56 infra and accompanying text.

25 In addition to the possibility of losing his rights in the lot upon abandonment of the cemetery, the lotowner is subject in some states to cancellation of his rights in unburied graves if he abandons the lot. See IND. ANN. STAT. \$21-402 (1950) (unincorporated associations only); IowA CODE ANN. \$\$ 566.20-.21 (1950) (ten years abandonment); Mich. STAт. ANN. \$21-843 (1935) (fifty years unpaid assessment); MInN. Stat. ANN. \$\$ 306.16, .20-.21 (Supp. 1959) (ten to twenty years); Neb. Rev. Stat. \$12-701 (1954) (ten years); S.D. Code \$11.1905 (1939) (ten years); TENN. CODE ANN. \$ 46-309 (Supp. 1960) (type of escheat); VT. STAT. ANN. tit. 18, $\S \S 5532-37$ (1959) (type of escheat); WASH. REv. CoDE $\$ 68.36 .010$ (Supp. 1955) (five years); WIs. STAT. \$157.11(7d) (1957). See generally Cemetery Legal Compass, Nov. 1938, pp. 121-26. Abandonment is defined as failure to care for the lot over a specified number of years, ranging from five to fifty. The funds received from the resale of the abandoned graves are used to care for graves having burials. Such laws are an attempt to prevent unused lots from becoming overgrown with weeds and thus making the cemetery unattractive. Although there is little doubt that the maintenance of attractive cemeteries is a desirable goal, there would appear to be constitutional problems in the taking, without compensation, of rights acquired prior to the passage of such a statute. No cases have been found in which the retroactive operation of such laws has been contested on constitutional grounds. See also Cemetery Legal Compass, Aug. 1943, pp. 374-75, where it is reported that an opinion of the Massachusetts Attorney-General ruled such a law unconstitutional on the grounds that the statute would create a debtor-creditor relationship between a lotowner and the cemetery solely on the basis of an omission on the part of the lotowner. 
lotowner-however it may be described-is terminated and the original fee owner regains full title. ${ }^{26}$ Owners of unused lots are probably entitled to compensation; ${ }^{27}$ if graves have had burials, the injury is alleviated by proper reinterment elsewhere. ${ }^{28}$ But should the owner whose deed purports to grant an absolute interest be governed by this proposition? Clearly, the ordinary reason for shifting labels is no longer present. However, it is not necessary to base the loss of property rights solely on the formalism that the owner's interest is now merely a license or an easement - under certain circumstances, an argument for the result can be made. Since the owner of an individual lot may have an interest so small that it is of little economic value once the cemetery has been abandoned and since the person desiring a tract would find it difficult to acquire the requisite number of these small interests, the development of the land would be effectively prevented if such a lotowner were allowed to retain his ground. By having the full interest in many small lots revert to the original fee owner (usually the cemetery corporation), these problems are avoided and the property once again assumes a commercially marketable size. This rule is particularly important with regard to those cemeteries strategically located near the center of large cities. Planning boards and civic improvement groups are often anxious to force abandonment in order to provide additional area for needed construction and development and to obtain the substantial increase in tax revenues which would result from the new uses. In contrast, when the lot is of sufficient size to be economically valuable in itself, there is no persuasive reason for depriving the owner of his interest in the lot and permitting the original fee owner to avoid his grant.

The compulsion to use real property labels, with their necessary implications, poses obvious difficulties. The judiciary is thereby compelled to choose between the extremes of fee simple or license, neither of which is adequate or desirable in all situations. On the other hand, recognition of the peculiar nature of cemetery property would lead to corresponding treatment keyed to the diverse needs of varying contexts.

\section{Cemetery Rules and Regulations}

If a cemetery is to be a place of tranquility suitable for relatives of the deceased to visit in their desire to ease the emotional shock of death and

26 Peebler v. Olds, 56 Cal. App. 2d 8, 132 P.2d 233 (Dist. Ct. App. 1942) ; Smith v. Ladage, 397 Ill. 336, 74 N.E.2d 497 (1947); Cemetery Legal Compass, June 1937, p. 49.

27 JACKson, op. cit. supra note 2, at 400 . Any other result would seem contrary to public policy.

28 Since the lotowner would have received all that he was entitled to receive, there should normally be no right to compensation unless the removal has been made to a poorly maintained cemetery or there has been some other diminution of the lotowner's rights. Since abandonment rarely occurs except in very old, poorly maintained cemeteries, the probability of such a diminution is small. In any case, such abandonment proceedings should be under court supervision. See also Went v. Methodist Protestant Church, 80 Hun 266, 30 N.Y. Supp. 157 (Sup. Ct. 1894), aff'd, 150 N.Y. 577, 44 N.E. 1129 (1896). 
to show respect for the dead, ${ }^{29}$ it seems necessary that the governing body of the cemetery have the power to promulgate and enforce rules regulating monuments, decoration of graves, and other aspects of the cemetery's operations. ${ }^{30}$ Furthermore, the governing body is obligated to maintain the grounds of the cemetery in safe condition ${ }^{31}$ and to prevent damage to adjoining lots when work is done on a particular lot. ${ }^{32}$ Since rules and regulations adopted prior to the purchase of a lot are almost universally listed in the deed or contract of sale, or are incorporated therein by reference, and since these rules are binding as a part of the contract, there is rarely any dispute as to their enforceability.33 In addition, the power to change these rules is customarily reserved in the original instrument. In other areas of the law, courts have generally refused to permit one party to make changes in a contract or to reserve the right to do so. ${ }^{34}$ But in

29 "The lot-holders themselves became subject to by-laws and regulations having reference to the institution as an entirety, and the perpetual preservation of the cemetery as an ornamental and convenient place for interment and for resort by the relatives of the dead." Close y. Glenwood Cemetery, 107 U.S. 466, 478 (1882). Cemetery authorities must consider "the sensibilities and feelings of other lot owners who may have different ideas of the appropriateness of proposed monuments and structures." Abell v. Proprietors of Green Mount Cemetery, 189 Md. 363, 366, 56 A.2d 24, 25 (1947).

30 For example, the sizes and types of vaults, the use of tents and lowering devices, and the conduct of people visiting the grounds.

31 Campbell v. Neshannock Presbyterian Church, $153 \mathrm{~Pa}$. Super. 246, 33 A.2d 33 (1943) (insure that work be done by competent men).

32 Orlowski v. St. Stanislaus Roman Catholic Church Soc'y, 161 Misc. 480, 292 N.Y. Supp. 333 (Sup. Ct. 1936), appeal as poor person denied, 12 N.Y.S.2d 350 'Sup. Ct. 1939) ; Campbell v. Neshannock Presbyterian Church, supra note 31.

33 West View Corp. v. Alston, $208 \mathrm{Ga} .122,65$ S.E.2d 406 (1951) (iterns may not be added to contract but cemetery may make rules more strict). But see Johnson $\mathrm{v}$. Cedar Memorial Park Cemetery Ass'n, 233 Iowa 427, 9 N.W.2d 385 (1943); Schaefer v. West Lawn Memorial Cemetery, 352 P.2d 744 (Ore. 1960). Disputes are also rare where state statutes make rules binding as against all purchasers. See, e.g., Car. Health \& Safetx Code \$ 8570; Tex. Rev. Crv. Stat. art. 912a.14 (1948). In some cases protection for the public is accomplished by requiring approval of rules by a cemetery board or department of public health. See MASs. AnN. LAws ch. 114, $\S \S 2,9$ (1957) ; N.Y. MEMrBersHrP. CoRP. LAwS \& 82. And many states have statutes specifically giving cemeteries the right to pass rules and regulations. See AlA. CoDE tit. 10, § 131 (1958); Alaska Comp. Laws ANN. \$ 36-5-8 (1949) ; Ark. Stat. ANN. \$ 82-416 (1960) (establishment of new cemeteries); CAL. Healtr \& SaFETy Code $\$ \S 8300,8302-08$, 8570; Conn. Gen. Stat. Rev. \$19-148 (1958); D.C. Cone ANn. $\$ 27-110$ (1951); IDAHo CodE ANN. \$28-202 (1947); Irl. AnN. Stat. ch. 21, § 46 (Smith-Hurd Supp. 1959); Ind. ANN. STAT. \$\$21-1011, -1023 (1950); IND. ANN. Stat. \$21-1029 (Supp. 1960); Kan. GeN. STAT. ANN. \$ 17-1309 (1949); MASS. ANN. Laws ch. $114, \S \S 2,9$ (1957); MICH. CoNp. Laws $\$ 456.106$ (1948) (lotowners are members of cemetery corporation); MinN. Stat. AnN. $\$ 306.08$ (1945); Mont. REv. CoDEs ANN. \$ 9-705 (1947) (mausoleums and columbariums); NEB. REv. STAT. $\$ \S 12-508,-517,-518$ (1954); N.J. REV. STAT. \$ 8:1-3 (1937); N.Y. MEMBERSHIP Corp. Laws \$82; Orka. Stat. Ann. tit. 8, \$ 5 (1951) ; Ore. Rev. Stat. \$97.710 (1953) (detailed list of permissible rules); S.D. CoDE $\$ 11.1908$ (1939); TENN. CoDE Ans. \& 46-302 (1956); TEX. Rev. CIv. Stat. art. 912a.14 (1948); VT. Stat. tit. 15, ch. 182, §4009 (1947) ; WASH. Rev. Code $\$ \$ 68.20 .060-.070$ (1951); WASH. Rev. CodE \$68.05.100 (Supp. 1953); WIS. STAT. \$157.11(2) (1957).

34 "Especially a reservation to either party of a future untrammelled right to determine the nature of the performance . . . has often caused a promise to be too indefinite for enforcement." WILLISTON, ConTracts \$37 (rev. ed. 1936). See also Carranor Woods Property Owners' Ass'n y. Driscoll, 106 Ohio App. 95, 153 N.E.2d 681 (1957) (restrictive covenant giving original grantor right to approve plans held void because no standards set in covenant). 
recognition of the unique character of a cemetery lot, courts have modified the usual law of contracts and have permitted the governing body to promulgate and enforce ${ }^{35}$ "reasonable" new or changed rules against prior purchasers. ${ }^{36}$ While purchasers are protected against drastic changes, ${ }^{37}$ the leeway granted the governing body is quite extensive, ${ }^{38}$ and is governed by a broad "rule of reason":

Those charged with the maintenance and supervision of a cemetery may impose reasonable regulations for the benefit of all lot holders. A regulation is reasonable if it promotes safe and efficient administration, protects all of the lot holders by preserving their lots, and does so without serious interference in matters of personal or familial concern in the conduct of the funeral and interment. ${ }^{39}$

Rules requiring that all foundations for monuments be built by the cemetery, ${ }^{40}$ or that all tents, grass mats, and lowering devices be supplied by the

35 See notes 40-46 infra and accompanying text.

36 Donohue v. Fitzsimmons, 95 N.J. Eq. 125, 122 Atl. 617 (Ch. 1923) ; Mansker v. Astoria, 100 Ore. 435, 198 Pac. 199 (1921) ; Pitcairn v. Homewood Cemetery Co., $229 \mathrm{~Pa} .18,77$ Atl. 1105 (1910) ; Dries v. Charles Evans Cemetery Co., 109 Pa. Super. 498, 167 Atl. 237 (1933). But see Slifer v. Greenmount Cemetery Co., 164 Pa. Super. 534,67 A.2d 584, 585 (1949) ("A power to regulate is not a power to destroy. It is not and cannot be a power to diminish the grant by subsequent restrictions which impose onerous financial burdens upon the lot-holders.") ; Estate of Blackburn, 230 Wis. 570, 284 N.W. 491 (1939) (cemetery held bound by general laws of contract). See generally Brennan, Law Governing Cemetery Rules and Regulations (rev. ed. 1951) [hereinafter cited as RuLES AND REGULATIONS]. This is the most comprehensive survey of cemetery rules and regulations, containing an extensively annotated set of recommended rules and regulations, as well as the author's opinion on doubtful points.

37 Steele v. Rosehill Cemetery Co., 370 I1l. 405, 19 N.E.2d 189 (1938), appeal dismissed, 307 U.S. 611 (1939) (cemetery tried to refuse to permit burial until back care charges accumulated without consent of lotowner were paid or until lot was placed under perpetual care); Mansker v. Astoria, supra note 36 (attempt to force endowment care); Slifer v. Greenmount Cemetery Co., sutpra note 36; Estate of Blackburn, sipra note 36 (decision said to be based on application of binding nature of deed). See generally Rules and Regulations 20-24.

38 Gasser v. Crown Hill Cemetery Ass'n, 103 Colo. 175, 84 P.2d 67 (1938); Luttenberger v. Restland Memorial Park Ass'n, 51 N.J. Super. 507, 144 A.2d 12 (Super. Ct. 1958) (upholding rule requiring vault to be set by cemetery where fee was charged for such service); Frank v. Clover Leaf Park Cemetery Ass'n, 48 N.J. Super. 453, 137 A.2d 605 (Super. Ct. 1957), modified and remanded, 29 N.J. 193, 148 A.2d 488 (1959); Ez Achaim Soc'y, Inc. v. Cohen, 15 Misc. 2d 540, 181 N.Y.S.2d 717 (Sup. Ct. 1958) (upholding rule requiring approval of monument inscriptions). See also Schaefer v. West Lawn Memorial Cemetery, 352 P.2d 744 (Ore 1960) (restriction requiring marker to be purchased through cemetery). Under proper rules a private cemetery may refuse to bury undesirable persons-for example, murderers. Cemetery Legal Compass, April 1947, p. 549. But see People ex rel. Paxton v. Bloomington Cemetery Ass'n, 353 I11. 534, 187 N.E. 455 (1933).

39 Ignatowski v. St. Mary's Polish Catholic Cemetery Co., $174 \mathrm{~Pa}$. Super. 52, 54, 98 A.2d 234, 235 (1953). Matters held not to be of personal or familial concern include tents, lowering devices, and similar items, Campbell v. Neshannock Presbyterian Church, $153 \mathrm{~Pa}$. Super. 246, 33 A.2d 33 (1943), and use of steel vaults, Dries v. Evans Cemetery Co., 109 Pa. Super. 498, 167 Atl. 237 (1933). But limiting the vault to a particular make is such an interference. Ignatowski v. St. Mary's Polish Catholic Cemetery Co., supra. See also Luttenberger v. Restland Memorial Park Ass'n, 51 N.J. Super. 507, 517, 144 A.2d 12, 17 (Super. Ct. 1958) (rule must pass "tests of clarity, uniformity, and equal applicability to all lot owners").

40 Pine Crest Memorial Park v. Burton, 312 S.W.2d 919 (Ark. 1958) (installing bronze markers); Terwilliger v. Graceland Memorial Park Ass'n, 59 N.J. Super. 
cemetery, ${ }^{41}$ or that all vaults be set by the cemetery ${ }^{42}$ have been upheld. Other rules regulating the alloy of bronze markers ${ }^{43}$ or the type of vault to be used ${ }^{44}$ have sometimes been voided-usually where there was substantial evidence that the cemetery was trying to secure a monopoly over supply of such items. ${ }^{45}$ However, even if monopolistic tendencies appear, a strong showing of reasonableness will be sufficient to sustain the rule.4B

Most frequently, litigation with regard to after-adopted rules has concerned regulations prohibiting the lotowner from planting or decorating the lot in the manner he desires. ${ }^{47}$ It has been almost uniformly held that the lotowner may decorate the lot himself or may use any sufficiently skilled

205, 157 A.2d 567 (Super. Ct. 1960) (installing bronze markers). But unreasonable rates may not be charged. Di Cristofaro v. Laurel Grove Memorial Park, 43 N.J. Super. 244, 128 A.2d 281 (Super. Ct. 1957). See also Donohue v. Fitzsimmons, 95 N.J. Eq. 125, 122 Atl. 617 (Ch. 1923) (regulation relating to setting monument and requiring permit of cemetery upheld). Contra, Chariton Cemetery Co. v. Chariton Granite Works, 197 Iowa 403, 197 N.W. 457 (1924) (foundations had been installed unsatisfactorily by cemetery). Brennan questions the validity of such a rule as applied against persons purchasing prior to its adoption. RULeS AND REGULATIONS 177-79. However, his only authority seems to be the Chariton case.

41 A. W. Carlson Inc v. Judd, 133 Conn. 74, 48 A.2d 269 (1946) ; Orlowski v. St. Stanislaus Roman Catholic Church Soc'y, 161 Misc. 480, 292 N.Y. Supp. 333 (Sup. C. 1936), appeal as poor person denied, 12 N.Y.S.2d 350 (Sup. C.t. 1939); Campbell v. Neshannock Presbyterian Church, 153 Pa. Super. 246, 33 A.2d 33 (1943); Rules and Regulations 63-66.

42 Lawson v. Woodmere, Inc., 217 F.2d 148 (4th Cir. 1954) (held not to be a violation of the antitrust laws); Tatman v. Rochester Lodge No. 47, I.O.O.F., 164 N.E. 718 (Ind. 1929) (no tendency to create monopoly); Luttenberger v. Restland Memorial Park Ass'n, 51 N.J. Super. 507, 144 A.2d 12 (Super. Ct. 1958); Rules and Regulations 40-46. Contra, Roselawn Memorial Park v. De Wall, 11 ill. App. 2d 66, 136 N.E.2d 702 (1956) (method used by cemetery shown to be inferior to that used by outsider).

43 Pine Crest Memorial Park v. Burton, 312 S.W.2d 919 (Ark. 1958) (alloy requirements not unreasonable but rule requiring laboratory analysis void). See also Johnson v. Cedar Memorial Park Cemetery Ass'n, 233 Iowa 427, 9 N.W.2d 385 (1943) (rule requiring bronze only upheld as against subsequent purchaser; court implied such a rule might be good even against prior purchaser if cemetery were memorial park).

44 People ex rel. Paxton v. Bloomington Cemetery Ass'n, 353 I1l. 534, 187 N.E. 455 (1933) (quo warranto proceeding); Ignatowski v. St. Mary's Polish Catholic Cemetery Co., $174 \mathrm{~Pa}$. Super. 52, 98 A.2d 234 (1953). Generally, no violation of antitrust laws is involved. See Lawson v. Woodmere, Inc., 217 F.2d 148 (4th Cir. 1954). Contra, Dries v. Evans Cemetery Co., 109 Pa. Super. 498, 167 Atl. 237 (1933) (steel vaults did not prevent sinking).

45 Pine Crest Memorial Park v. Burton, 312 S.W.2d 919 (Ark. 1958) (laboratory analysis requirement tended toward monopoly); People ex rel. Paxton v. Bloomington Cemetery Ass'n, 353 IIl. 534, 187 N.E. 455 (1933) (quo warranto proceeding); Ignatowski v. St. Mary's Polish Catholic Cemetery Co., $174 \mathrm{~Pa}$. Super. 52, 98 A.2d 234 (1953). See also Frank v. Clover Leaf Park Cemetery Ass'n, 48 N.J. Super. 453, 137 A.2d 605 (Super. Ct. 1957), modified and remanted, 29 N.J. 193, 148 A.2d 488 (1959).

46 Pine Crest Memorial Park v. Burton, 312 S.W.2d 919 (Ark. 1958) (high lead content would be harmful in bronze marker); Schaefer v. West Lawn Memorial Cemetery, 352 P.2d 744 (Ore. 1960) (cemetery would purchase from any bronze manufacturer, but marker had to be purchased through cemetery); Dries v. Evans Cemetery Co., $109 \mathrm{~Pa}$. Super. 498, 167 Atl. 237 (1933) (rule preventing use of steel vaults adopted in order to prevent the grave from sinking).

47 E.g., Scott v. Lakewood Cemetery Ass'n, 167 Minn. 223, 208 N.W. 811 (1926); Cedar Hill Cemetery Co. v. Lees, 22 Pa. Super. 405 (1902); Rules and Regulations 93-111. 
agent to decorate it ${ }^{48}$ so long as plants or materials forbidden by reasonable rules are not used. Although there has been no case directly in point, it would not seem unreasonable for the cemetery to require that it be notified as to the nature of such work and when it is to be done and that it be permitted to inspect the decorations when completed. ${ }^{49}$ Such requirements are designed to prevent substandard work and trespasses on adjoining lots. ${ }^{50}$

Several reasons have been advanced to justify the binding effect of after-adopted rules and regulations on purchasers of cemetery lots. One authority suggests that:

Many of the rules and regulations are merely management or administrative rules necessary to keep the cemetery or park clean and economically maintained. To have to propose each administrative rule to a group of lot owners for their approval before it can be carried out would be impossibly cumbersome . . . . As times change and new machinery changes, maintenance and administrative customs and policies, rules and regulations must be changed. To run the cemetery efficiently, management must retain the right to change these rules and regulations and, in general, lot owners wholeheartedly support that right of management. ${ }^{51}$

Jackson contends that such changes are merely an extension of the original contract which reserved the right to amend the rules. ${ }^{52}$ Another authority has suggested that this power is analogous to a municipality's power to regulate the use of property by means of zoning laws. ${ }^{53}$ For the good of

${ }^{48}$ E.g. Scott v. Lakewood Cemetery Ass'n, supra note 47; Mansker v. Astoria, 100 Ore. 435, 198 Pac. 199 (1921); Benson v. Laurel Hill Cemetery Co., 68 Pa. Super. 242 (1917). See also Chariton Cemetery Co. v. Chariton Granite Works, 197 Iowa 403, 197 N.W. 457. (1924) (skilled agent may install foundation where cemetery had not installed satisfactory foundations); Campbell v. Neshannock Presbyterian Church, $153 \mathrm{~Pa}$. Super. 246, 33 A.2d 33 (1943). Contra, Cedar Hill Cemetery Co. v. Lees, supra note 47 (pleasant appearance of cemetery can be maintained only by cemetery regulation of work). Cedar Hill was apparently approved in Slifer v. Greenmount Cemetery Co., $164 \mathrm{~Pa}$. Super. 534, 67 A.2d 584 (1949).

49 For a similar situation where the court rejected as unreasonable a rule requiring bronze markers to be installed by the cemetery but implied that it could require such installation to be under the cemetery's supervision, see Frank v. Clover Leaf Park Cemetery Ass'n, 48 N.J. Super. 453, 137 A.2d 605 (Super. Ct. 1957), modified and remanded, 29 N.J. 193, 148 A.2d 488 (1959). Brennan also suggests that such a rule would be valid. RULES AND REgulations 111-14.

50 Orlowski v. St. Stanislaus Roman Catholic Church Soc'y, 161 Misc. 480, 292 N.Y. Supp. 333 (Sup. Ct. 1936), appeal as poor person denied, 12 N.Y.S.2d 350 (Sup. Ct. 1939) ; Scott v. Lakewood Cemetery Ass'n, 167 Minn. 223, 208 N.W. 811 (1926).

51 Letter From James Worley, executive vice president, American Cemetery Ass'n, to Montefiore Cemetery Co., Philadelphia, Pa., Aug. 16, 1960. This letter does not represent the official opinion of the ACA but only the personal opinion of Mr. Worley based on his belief as to the consensus of the association.

52 Jackson, The Law of Cadavers 383 (2d ed. 1950).

53 Letter From Harry E. Sanders, secretary, Cemetery Ass'n of Pennsylvania, to Montefiore Cemetery Co., Philadelphia, Pa., Aug. 17, 1960. Cemetery rules which prohibit or require certain future acts, such as those requiring that tents be supplied by the cemetery, or that no steel vaults may be used after a certain date, are analogous to those provisions of zoning laws which prevent certain types of future development. There also is a nonconforming use problem similar to that of 
the cemetery as a unit, the rules and regulations must be amendable and those amendments must be binding so that fresh ideas-such as the use of concrete vaults-may be fully utilized and so that changing conditions may be met. ${ }^{54}$ New developments and greater experience often indicate that modifications of current practice would improve the safety and attractiveness of the cemetery. Furthermore, lotowners frequently attempt to decorate their own lots in such a manner as to trespass upon ${ }^{55}$ or otherwise hinder ${ }^{56}$ adjoining lotowners. This can be stopped more quickly and effectively by cemetery regulation than by action by the aggrieved lotowner. It is, therefore, a natural consequence of the governing body's responsibility for perpetually preserving the cemetery in a manner suitable for the burial of the dead that such rules be enforceable.

\section{Racial aNd ReLigious Restrictions}

\section{Racial Restrictions}

A more serious question arises when a cemetery, by rules and regulations or by contract, seeks to establish racial or religious restrictions for burials in its lots. Of these, racial restrictions are more frequently subjected to attack. State courts have repeatedly held that racial restrictions are binding, ${ }^{57}$ at least against persons purchasing lots after the enactment

zoning. This occurs when cemetery attempts to force changes in existing plantings or monuments. In determining the validity of these rules, the standard of "reasonableness" would require greater support than a rule which merely attempts to regulate future actions. However, it would seem that rules which gave such "nonconforming" uses sufficient time to make changes would be reasonable.

54 Letter From Raymond Louis Brennan, general counsel, Interment Ass'n of California, to Montefiore Cemetery Co., Philadelphia, Pa., Sept. 1, 1960: "As an example, which is rather pointed only for the purpose of the discussion, some of the early rules and regulations provided that horse drawn carriages should travel at a certain limited rate of speed! This was the day before the automobile and, obviously, nothing was said about automobiles. That a cemetery should be able to adopt rules and regulations regulating the use of automobiles in the cemetery grounds is good and sound. Some of the present rules bar horse drawn carriages from coming into the cemetery .... Another illustration is where wooden boxes were originally permitted when the lot was sold, and under present conditions the new rule should require a box made of concrete to prevent the sinking of graves." This justification is also mentioned in Letter From Martin Gaudian, executive vice president, National Ass'n of Cemeteries, to Montefiore Cemetery Co., Philadelphia, Pa., Oct. 3, 1960. This letter does not represent the official opinion of the NAC but only Mr. Gaudian's personal beliefs.

55 Orlowski v. St. Stanislaus Roman Catholic Church Soc'y, 161 Misc. 480, 292 N.Y. Supp. 333 (Sup. Ct. 1936), appeal as poor person denied, 12 N.Y.S.2d 350 (Sup. Ct. 1939) (exception to unlimited right of lotowner to adorn and decorate).

56 For example, by erecting monuments with inscriptions which upset other visitors to the cemetery. See $\mathrm{E}_{z}$ Achaim Soc'y, Inc. v. Cohen, 15 Misc. 2d 540, 181 N.Y.S.2d 717 (Sup. Ct. 1958) (inscription read: "Beneath This Stone Lies A Woman Who Loved Life But Was Murdered By A Doctor Whose Name Is Not Worthy to Appear Here").

57 Long v. Mountain View Cemetery Ass'n, 130 Cal. App. 2d 328, 278 P.2d 945 (Dist. Ct. App. 1955); Forest Lawn Memorial Park Ass'n v. De Jarnette, 79 Cal. 
of the rule.58 Reacting to this practice, several state legislatures have enacted statutes specifically prohibiting racial restrictions ${ }^{59}$ and, in some cases, refusal to bury for racial reasons has been made criminal. ${ }^{60}$ Where such legislation has been passed, courts have been willing to give broad scope to the policy embodied in the act and have stricken restrictive clauses even before a refusal to bury. ${ }^{61}$

Even in the absence of a statute prohibiting such restrictions, the validity of racial restraints is in doubt. Much of the uncertainty has been created by Rice v. Sioux City Memorial Park Cemetery, Inc., ${ }^{62}$ in which defendant, relying upon a contractual restriction, had refused to bury a person having eleven-sixteenths Winnebago Indian blood. The widow, who was the original purchaser, sued for damages and asked that the covenant be declared void. The Supreme Court of Iowa ${ }^{63}$ upheld the validity of the racial restraint, distinguishing earlier United States Supreme Court decisions on the ground that state aid was not here given to the party seeking to enforce the covenant. On writ of certiorari, ${ }^{64}$ an evenly divided Court affirmed the Iowa court's holding without opinion. ${ }^{65}$ But apparently the Court was unaware that, prior to the grant of certiorari, Iowa had

App. 601, 250 Pac. 581 (Dist. Ct. App. 1926) ; Long v. Mountain View Cemetery Ass'n, No. 238848 (Cal. Super. Ct. 1953), in Cemetery Legal Compass, July 1953, p. 853; People ex rel. Gaskill v. Forest Home Cemetery Co., 258 IIl. 36, 101 N.E. 219 (1913), appeal dismissed, 238 U.S. 606 (1915); Rice v. Sioux City Memorial Park Cemetery, Inc., 245 Iowa 147, 60 N.W.2d 110 (1953), aff'd per curiam by an equally divided Contrt, 348 U.S. 880 (1954), vacated on rehearing and cert. dismissed, 349 UU.S. 70 (1955); Leathers v. Odd Fellows Rest, 138 La. 15 , 69 So. 858 (1915). For an extreme example of this type of restriction, see College Park Cemetery Properties, Inc v. Cottongim, 185 Ga. 741, 196 S.E. 409 (1938). In College Park, the cemetery had a rule providing that no one except white persons would be permitted to do any work on any of the lots unless such person be accompanied by a lotowner or a member of the lotowner's family. Where a florist had used colored employees, the court refused to modify a partial injunction directing that colored employees were to work under the direct control of defendant florist and only after approval by superintendent and lotowner. Contra, Memphis S.L.R.R. v. Forest Hill Cemetery Co., 116 Tenn. 400, 94 S.W. 69 (1906).

$58 \mathrm{Mt}$. Moriah Cemetery Ass'n v. Commonwealth, $81 \mathrm{~Pa} .235$ (1876) (person purchasing prior to passage of rule held not bound despite claim of other lotowners and cemetery that large loss in value would result unless rule upheld. But see RULES AND REGULATIONS 57-63.

59 Iowa Code ANN. \$ 566A.8 (Supp. 1960) ; N.J. Rev. Stat. \$ 10:1-9 (1960); N.Y. Membership CoRp. Laws $\$ \$ 4(2)$, 88; N.Y. Pen. Laws $\$ 514(2)$; S.D. Code $\S 11.19 A 08$ (Supp. 1960).

60 N.J. Rev. Stat. $\$ 10: 1-9$ (1960) ; N.Y. Pen. Laws $\$ 514(2)$. See also In the Matter of George Washington Memorial Park Cemetery Ass'n, 52 N.J. Super. 519,145 A.2d 665 (Super. Ct. 1958), upholding the New Jersey statute in an action to strike a racial covenant in quo warranto proceedings.

61 In the Matter of George Washington Memorial Park Cemetery Ass'n, supra note 60 .

62245 Iowa 147, 60 N.W.2d 110 (1953), aff'd per curiam by an equally divided Court, 348 U.S. 880 (1954), vacated on rehearing and cert. dismissed, 349 U.S. 70 (1955).

63245 Iowa 147, 60 N.W.2d 110 (1953).

64347 U.S. 942 (1954).

65348 U.S. 880 (1954). 
enacted a statute forbidding racial restrictions on cemetery lots. ${ }^{66}$ On rehearing, the then fully informed Court determined that the existence of the statute necessitated vacation of the affirmance and withdrawal of certiorari on grounds that it had been improvidently granted. ${ }^{67}$ This set of opinions has been interpreted as upholding the cemeteries' right to make and enforce racial restrictions. ${ }^{68}$ However, if certain Supreme Court opinions are pressed to their full logical limits, all racial restrictions are constitutionally unenforceable by state court action. Shelley $v$. Kraemer ${ }^{69}$ held that the state court's enforcement of a racial covenant designed to preclude the ownership or occupancy of real estate by Negroes was sufficient state action to support invocation of the fourteenth amendment prohibitions against deprivation of equal protection of the laws. Likewise, Barrows $v$. Jackson ${ }^{70}$ prevented a state court from allowing damages for breach of such a covenant. If this concept of state action is generally applicable, it is evident that state court enforcement of burial restrictions based on race will not be allowed to stand.

The difficulties inherent in reading Shelley as prohibiting state effectuation of any private racial bigotry ${ }^{71}$ have prompted Professor Pollak ${ }^{72}$ to suggest that these decisions do not ban all such state activity, but interdict only that utilization of state power which forces an individual to discriminate. ${ }^{73}$ By this analysis an attempt to ban resale of lots to members of a particular race is unenforceable inasmuch as the agreement would, if enforced, preclude the original purchaser's subsequent sale to a person of that race, regardless of his own prejudices or lack of them. On the other hand, a provision forbidding burial because of race would be enforced against the original purchaser since the state power is utilized not to force the buyer to discriminate against others but merely to uphold the voluntary private perversity of the cemetery. ${ }^{74}$ Should the original purchaser transfer his interest, ${ }^{76}$ the restriction on burial would fall within the reach of the four-

66 Iowa CoDE ANN. \$566A.8 (Supp. 1960). This statute was apparently applicable in all cases except that of petitioner. Iowa Sess. Laws 1953 , ch. 84, § 12 . Mr. Justice Douglas noted that this circumstance raised an equal protection problem as serious as the question raised on the merits. 349 U.S. 70, 80 (1955) (dissenting opinion).

67349 U.S. 70 (1955).

68 Letter From James Worley, supra note 51.

69334 U.S. 1 (1948).

70346 U.S. 249 (1953). But see Johnson v. Levitt \& Sons, Inc. 131 F. Supp. 114 (E.D. Pa. 1955); Dorsey v. Stuyvesant Town Corp., 299 Nं.Y. 512, 531-36, 87 N.E.2d 541, 549-51 (1949), cert. denied, 339 U.S. 981 (1950).

71 See Wechsler, Toward Neutral Principles of Constitutional Laze, 73 HARp. L. REv. 1, 29-30 (1959).

72 Pollak, Racial Discrimination and Judicial Integrity: $A$ Reply to Professor Wechsler, 108 U. PA. L. REv. 1 (1959).

73 Id. at $12-13$.

74 See Civil Rights Cases, 109 U.S. 3 (1883) (private action not within scope of fourteenth amendment). This idea was a basis of the Iowa Supreme Court's decision in the Rice case.

75 The cemetery could require that the lot be resold only to the cemetery or only after the cemetery has refused to repurchase. 
teenth amendment, for to enforce the restraint against a later purchaser would effectively remove that purchaser from the class of potential buyersthe purchase would be economically useless. ${ }^{76}$ In such a case a state court's enforcement of the restriction on burial would have the same effect as enforcing a restriction on resale: ${ }^{77}$ in both the racial class discriminated against would be barred from purchasing because of state court action which forces the original purchaser to discriminate against members of a class. In the one instance, he cannot convey anything of economic value; in the other, he cannot convey at all. ${ }^{8}$

A more expansive view of the Shelley doctrine than that taken by Pollak would include in the fourteenth amendment protection all dealings except an initial refusal to deal with a certain racial class. ${ }^{79}$ If legal action is taken by the individual against whom the cemetery discriminated, state judicial action-or inaction- "enforcing" the refusal would take the negative form of a nonsuit or dismissal rather than the positive enforcement of a discriminatory contract. On the basis of this constitutional line, a cemetery would be free to refrain from selling lots to persons of a given race in the absence of a state statute making such conduct unlawful.

Cemetery racial restrictions might be brought within the scope of the fourteenth amendment by the operation of doctrines other than that of the Shelley case. Clearly, if the cemetery is municipally owned or managed, the constitutional prohibition is effective. ${ }^{80}$ But all cemeteries-not merely those which are municipally operated-perform a vital public function, both in providing for the healthful disposal of the dead and in offering a place where sentiment and tradition may be preserved. Though these activities are not as apparently governmental as were those of the company town in Marsh v. Alabama, ${ }^{81}$ they do evidence the quasi-public nature of cemetery

76 This is very similar to the situation in Barrows v. Jackson, 349 U.S. 249 (1953), except that in Barrows it was the seller who was economically penalized whereas here it is the buyer who suffers.

$\mathbf{7 7}$ See Barrows v. Jackson, supra note 76 , which was also an attempt to use an indirect approach in enforcing the covenant by suing the seller for damages. The Supreme Court ignored the form of the action-as well as overriding serious questions of standing to litigate-in order to void the provision.

78 Whether the Rice situation presents unconstitutional discrimination under Pollak's theory is unclear. Is the owner of the lot not forced to limit her choice as to whom she will allow to be buried in her lot? Professor Pollak apparently thinks otherwise. See Pollak, sipra note 72 , at 15 n.57.

79 Compare Civil Rights Cases, 109 U.S. 3 (1883). See also Levitt \& Sons, Inc. v. Division Against Discrimination, 31 N.J. 514,158 A.2d 177, appeal dismissed, 363 U.S. 418 (1960). The cemetery could also require that any person desiring to resell his lot offer it to the cemetery first.

80 See Pennsylvania v. Board of Directors of City Trusts, 353 U.S. 230 (1957). An interesting problem is raised if the municipality attempts to maintain "separate but equal" cemeteries. The widely ranging per curiam opinions in the aftermath of Brown v. Board of Educ., 347 U.S. 483 (1954), reargument, 349 U.S. 294 (1955), indicate that such an arrangement would be unconstitutional. See Holmes v. City of Atlanta, 223 F.2d 93 (5th Cir.), vacated, 350 U.S. 879 (1955) (per curiam); Dawson v. Mayor of Baltimore, 220 F.2d 386 (4th Cir.), aff'd per curiam, 350 U.S. 877 (1955).

81326 U.S. 501 (1946). See also Levitt \& Sons, Inc. v. Division Against Discrimination, 31 N.J. 514, 158 A.2d 177 (1960) (state law required FHA-financed development to deal with all buyers without discrimination). 
operation. Whether they are sufficient to denominate cemetery action as that of the state is questionable. And even if the Marsh theory does encompass cemeteries, the resulting rule must be framed so as to reflect certain basic differences among cemeteries. The nonsectarian profit cemetery or memorial park should not be permitted to restrict on a racial basis inasmuch as it holds itself out as a place for fulfilling the community's needs for a safe and attractive place for the burial of the dead. If the operators of such a cemetery are restricting sales by race, they are likely doing so for economic reasons alone, ${ }^{82}$ and there is relatively little justification for allowing an organ of the community to maintain an economic advantage for one group by depriving another group of its position as a part of the public which is supposedly being served. Nor should cemeteries operated by and for the benefit of religious societies-whether for profit or not ${ }^{83}$ be able to claim a valid religious restriction if persons of the race against which the restriction is directed were accepted into the society during life. However, in the case of "lotowner-owned" nonprofit cemeteries, a different rule is supportable. These cemeteries more nearly approach the characteristics of a private club; ${ }^{84}$ they do not purport to serve the community at large. Inasmuch as the selection of a resting place for the dead is a matter of private, emotional concern, there should be some outlet provided for those whose prejudices are so strong that such a restriction is essential for their peace of mind. ${ }^{85}$ Note, however, that any such theory of private association would not, of course, release a cemetery from the operation of the Shelley doctrine. ${ }^{86}$

\section{Religious Restrictions}

Religious restrictions occupy a fundamentally different position. Classification along religious lines by cemeteries is not unreasonable, since for thousands of years burial-in both savage and civilized countries ${ }^{87}$

82 The alternative reason would be discrimination for discrimination's sake-obviously within the fourteenth amendment if the cemetery's action can be viewed as that of the state.

83 Since cemeteries run by religious societies are not profitmaking organizations in the ordinary sense, restriction of the rule to profit cemeteries would result in its inapplicability in this area. Such cemeteries hold themselves out as being open to members of the church by which they are operated; it therefore seems inadvisable to permit the possibility that a church member may be barred from the church burying grounds because of race. Inasmuch as burial within the confines of the church cemetery is likely to be one of the more important rights of church membership, a deprivation of these rights constitutes an unequal situation-one not unlike that prevailing
when education is segregated.

84 This view is suggested by a letter quoted in Cemetery Legal Compass, July 1953 , p. 854.

85 "We must never forget that cemeteries are primarily sacred memorial places. Without respect for identity, nothing can be remembered. Similarly, one cannot establish a memorial to an ideal, a person, or a group whom he is prohibited from identifying. People should have and must have the right freely to establish their own associations." Ietter From James Worley, supra note 51 .

86 See notes 69-78 supra and accompanying text.

87 JACKsoN, op. cit. supra note 52, at 1-3, 13. 
has been a religious rite. ${ }^{88}$ Indeed, until comparatively recent times, control of the burial and the cemetery was almost completely controlled by the ecclesiastical authorities to the exclusion of secular courts, ${ }^{89}$ and today burial continues to be basically a religious rite. ${ }^{90}$ In many faiths detailed rules are administered by ecclesiastical authorities. ${ }^{91}$ Refusal to permit burial in consecrated ground is still considered a most severe sanction by some religious groups. ${ }^{92}$

It is not surprising, therefore, that courts have been reluctant to interfere with religious restrictions or administration. ${ }^{93}$ The question seems to be so well settled that cases requiring a decision on the subject have rarely come before the courts in recent years. Even in the absence of a rule restricting burial to members of the faith, courts have frequently refused to order the burial of nonbelievers in a strictly religious cemetery. ${ }^{24}$ Per-

$88 I d$. at 1-18.

89 For a discussion of early burial practices, see Gilbert v. Buzzard, 3 Phill. 335, 161 Eng. Rep. 1342 (Ecc. 1820).

90 See Kerin, Christian Burial Problems, 15 JuRIst 252 (1955) (Roman Catholic rules for burial); Cemetery Legal Compass, Feb. 1943, pp. 349-51 (Christian burial). But see Russian Orthodox Church Appeal, 397 Pa. 126, 152 A.2d 489 (1959), where it was held that a cemetery was not a use of land for religious practices within the meaning of a zoning act. The facts that the owner was a religious body and that burial rites were spiritually essential were unpersuasive. Compare Williams v. Ramey, 201 Ga. 737, 41 S.E.2d 159 (1947).

91 See Kerin, supra note 90.

92 For example, the Roman Catholic Church refuses to bury suicides. Kerin, supra note 90, at 263-64. See generally Cemetery Legal Compass, April 1947, pp. $549-51$, citing many early cases in which the right of burial in a religious cemetery was refused as a result of a violation of the rules of the faith.

93 E.g., Dwenger v. Geary, 113 Ind. 106, 14 N.E. 903 (1888) ; Seifer v. Schwimmer, 166 Misc. 329, 1 N.Y.S.2d 730 (Sup. Ct. 1937); People ex rel. Coppers v. Trustees of St. Patrick Cathedral, 21 Hun 184 (N.Y. Sup. Ct. 1880) ; Brnilovich v. St. George Independent Serbian Orthodox Church, 326 Pa. 218, 191 At1. 655 (1937). Most authorities in the field are in accord. "A religious restriction is something different. Anyone is eligible to become a member of a religious sect, and if he does, he would be entitied to the use of the religious cemetery. I can see the reason why those of a particular religious group would want to be in a cemetery, or an area within a cemetery, restricted to members of their own religious faith. Yes, I believe that religious restriction covenants are valid, and I am inclined to think that even a statute that would attempt to tamper with this would be unconstitutional." Letter From Raymond Louis Brennan, supra note 54. "As I've already pointed out, burial is a semi-sacred rite. Surely Roman Catholics, Jews, Methodists, Lutherans, Buddhists would be deprived of one of their inalienable rights if they could not set aside burying grounds for themselves." Letter From James Worley, supra note 51. See also Cal. Health \& SafeTY Code $\$ 7980$; Ind. ANN. Stat. \$21-1003 (1950); JACKSON, op. cit. supra note 52 , at 379.

94 E.g., People ex rel. Coppers v. Trustees of St. Patrick's Cathedral, 21 Hun 184 (N.Y..' Sup. Ct. 1880): "Where a party applies for a burial plot, at the office of a distinctively Roman Catholic cemetery, it is with the tacit understanding that he is either a Roman Catholic, and as such eligible to burial, or at least that he applies on behalf of those who are in communion with the church . . . The parties may, notwithstanding, contract, if they choose, in such a manner that any one, even a Buddhist, Mohammedan, or avowed Atheist, will have a legal right to sepulture in the plot; and the law will give effect to their bargain. But to accomplish such an object, to contract in entire disregard of the church laws, usages and customs applicable to the cemetery, to give the vendee an absolute right to disturb what is believed to be the spiritual harmony of the surroundings, a very different instrument from this simple receipt would have to be secured." Id. at 194. 
mitting such restrictions has the support not only of a long tradition of noninterference but also recognizes the necessity imposed by the practical differences between the burial rites of the various religions. ${ }^{95}$ The problems of properly consecrating ground for Roman Catholic burial ${ }^{86}$ and the requirements of segregating burials of men from women under traditional Orthodox Judaism ${ }^{97}$ are too diverse to require intermixing. Furthermore, such restrictions are so tied up with the exercise of religion that they might even be regarded as coming within the constitutional protection of the first and fourteenth amendments. This pervading religious atmosphere which surrounds burial is descriptive of all types of cemeteries, ${ }^{98}$ not merely those directly affiliated with a church. The private corporation which burys Jews only is essentially a cemetery of that faith, and thus its rules are not of an arbitrary character. ${ }^{80}$

\section{Protection of the Purchaser's Interest}

Although rules and regulations will often have provisions designed to protect the lotowner's interests, occasionally it is necessary to resort to relief drawn from other fields of the law. Because a cemetery lot is a type of real property, ${ }^{100}$ an individual lotowner may bring an action for trespass. ${ }^{101}$

95 "Moreover, the burial ceremony of each church is a part of its ritual and they differ one from the other. The different burial rituals evidently were a factor in establishing separate burial grounds in the early days of the country's history. (Possibly those who believe in making everything uniform from the cradle to the grave would make light of the religious convictions of people who would prefer a resting place with those of like faith.)" Letter From Harry $\mathrm{E}$. Sanders, supra note 53. For an extreme example of these religious differences, note the unique customs of the Parsees: "This almost fanatic devotion to ceremonial purity accounts for their unique method of disposing of the bodies of the dead. Since they reverence the earth as well as the fire, they neither bury nor cremate corpses, but expose them on dakhmas, 'Towers of Silence,' in secluded places where birds come and devour the flesh, and the bones are left to dry. Twice a year the bones are collected and cast into the central well of the dakhma where they are eventually reduced to dust by the action of sun, rain, and air." PotTer, FAITHS MEN LIVE By 45 (1954). See also Burial Customs in the Land of the Rising Sun, Am. Cemetery, Jan. 1960, pp. 17-21.

96 Kerin, Christian Burial Problems, 15 JuRIsT 252 (1955).

87 This custom has been almost abandoned in recent years. However, many unusual customs still prevail. See Mayerberg, Burial Customs Observed by People of the Jewish Faith, Am. Cemetery, March 1960, p. 27.

98 Municipally operated cemeteries must be distinguished. Although one might expect to find in them a "religious" atmosphere, there are no natural religious limits, for the cemetery purports to serve the entire city or town. The dominant characteristic is government service rather than attachment to a particular religion. Discrimination based on religion by such a cemetery would be unreasonable and violative of the fourteenth amendment.

89 Of course, a religious restriction may be arbitrary. Thus, a rule allowing burial of all but Jews would raise an equal protection question. On the problems of state action in such a case, see notes 69-86 supra and accompanying text.

100 See notes 9-20 supra and accompanying text.

101 Bushers v. Graceland Cemetery Ass'n, 171 F. Supp. 205 (E.D. Ill. 1958); Smith \& Gaston Funeral Directors, Inc. v. Wilson, 262 Ala. 401, 79 So. 2d 48 (1955); West View Corp. v. Alexander, 83 Ga. App. 810, 65 S.E.2d 38 (1951); Humphreys v. Bennett Oil Corp., 195 La. 531, 197 So. 222 (1940). But there is no right of ejectment. Stewart v. Garrett, 119 Ga. 386, 46 S.E. 427 (1904). Contra, Corkill v. Calvary Cemetery Ass'n, 29 Ohio Op. 554 (C.P. 1944) (ejectment of burial even where title obtained by adverse possession). See generally Cemetery Legal Compass, May 1958, pp. 1085-86; Note, Cemeteries, Nature of Interest of "Ovener" of Cemetery Lot-Trespass, Remedies at Law \& in Equity, 15 B.U.L. REv. 307 (1935). 
In several instances, recovery on a theory of trespass has been allowed where oil drilling rigs have been erected on cemetery grounds in order to tap fields beneath the cemetery, even though the particular lot was untouched. ${ }^{102}$ However, in one case the slanting of an oil well into cemetery grounds from outside, with the consent of the cemetery management, was held not to be an actionable trespass. ${ }^{103}$ The dumping of mine refuse on a grave was held to be a continuing trespass, ${ }^{104}$ as was burial of a stranger in the lot. ${ }^{105}$ This action is often confused with an action for desecration of the grave, which arises when one not entitled to perform work on the lot destroys plants or removes or defaces a monument. ${ }^{106}$ The difference is of significance if a relative who is not the owner of the lot brings the action, ${ }^{107}$ or if the jurisdiction in question does not allow damages for mental anguish in trespass actions. ${ }^{108}$

Although interference with the use of roads or pathways can otherwise be enjoined, ${ }^{109}$ the cemetery frequently reserves the right to replat roads and pathways. ${ }^{110}$ Several states have enacted statutes permitting such replatting, with the condition that the funds received must be either contributed to maintenance trust funds or otherwise used for the betterment of the cemetery. ${ }^{111}$ Replatting is rarely undertaken until a cemetery is almost filled and thus the funds received generally benefit all lotowners.

102 Bushers v. Graceland Cemetery Ass'n, 171 F. Supp. 205 (E.D. Ill. 1958) ; Humphreys v. Bennett Oil Corp., 195 La. 531, 197 So. 222 (1940). See also Gibson v. Berry Cemetery Ass'n, 250 S.W.2d 600 (Tex. 1952) (action by relatives to determine their right to grant oil lease). See generally Note, Oil and Gas: Developing Cemeteries in Oklahoma for Oil and Gas Purposes, 8 OKLA. L. REv. 474 (1955).

103 McCullough v. Long Beach Cemetery Ass'n, No. 400134 (Cal. Super. Ct. 1937), in Cemetery Legal Compass, March 1937, p. 37; 2 Casner, AMrerican LAw OF PROPERTY § 10.137 (1952).

104 Fergerson v. Utilities Elkhorn Coal Co., 313 S.W.2d 395 (Ky. 1958).

105 Manewitz v. Chevra Ahawath Abraham B'nai Kolo, Inc., 195 Misc. 473, 87 N.Y.S.2d 740 (Sup. Ct. 1949) ; O'Shaughnessy v. John J. Barnett, Inc., 186 Misc. 1040, 66 N.Y.S.2d 4 (Sup. Ct. 1946).

106 E.g., Thomas v. Mobley, 118 So. 2d 476 (La. 1960) (action for trespass would have been successful). In many states the disturbance of a grave or monument is a criminal offense. See, e.g., MD. ANN. CoDE art 27, \&267 (1957); NEB. REv. STAT. \$28-570 (1956).

107 King v. Smith, 236 N.C. 170, 72 S.E.2d 425 (1952). See also Thomas v. Mobley, supra note 106. But see Leleux v. Viator, 55 So. $2 \mathrm{~d} 662$ (La. 1951).

108 Compare Manewitz v. Chevra Ahawath Abraham B'nai Kolo, Inc, 195 Misc. 473, 87 N.Y.S.2d 740 (Sup. Ct. 1949), with Bushers v. Graceland Cemetery Ass'n, 171 F. Supp. 205 (E.D. Ill. 1958), and Smith \& Gaston Funeral Directors, Inc. v. Wilson, 262 Ala. 401, 79 So. 2d 48 (1955) (recovery allowed in trespass).

109 Burke v. Wall, 80 La. 38 (1877); Dunbar v. Oconomowoc Cemetery Ass'n, 189 Wis. 164, 207 N.W. 265 (1926) ; Letter From Raymond Louis Brennan, general counsel, Interment Ass'n of California, to Montefore Cemetery Co., Philadelphia, Pa., Sept. 1, 1960; Letter From James Worley, executive vice president, American Cemetery Ass'n, to Montefiore Cemetery Co., Philadelphia, Pa., Aug. 16, 1960. But see City View Cemetery Ass'n v. Salem Mausoleum \& Crematorium, 209 Ore. 199,305 P.2d 379 (1956) (dictum) (lotowner has no interest in land over which thoroughfare has been constructed).

110 Rules aNd Regulations 120-21 (1951).

111 See, e.g., Ore. Rev. Stat. $\$ \$ 97.360-430$ (Supp. 1959); Wis. Stat. AnN. $\S \S 157.08(4), .09$ (1957) (funds may be used for other purposes). This approach is widely approved. Letter From Raymond Louis Brennan, supra note 109; Letter From Martin Gaudian, executive vice president, National Ass'n of Cemeteries, to Montefiore Cemetery Co., Philadelphia, Pa., Oct. 3, 1960. 
In many states cemetery lots are freed by statute from attachment and execution. ${ }^{112}$ In some states, this exemption is considered a part of the freedom granted to homesteads generally; ${ }^{113}$ in others, it merely represents a continuation of a general policy to protect cemetery property and to prevent it from becoming an item of commerce. ${ }^{114}$ While this protection is usually extended to all cemetery lots, ${ }^{115}$ one state limits the exemption to those lots in which a burial has been made.110 Inasmuch as lots purchased in advance of need are generally located as near to burials of other members of the family as possible, allowing attachment prior to burial may interfere with one of the basic concepts of cemetery law-that the right to be buried with one's family should be protected. By permitting attachment of such lots, the family group may be split, for lots immediately adjacent to prior burials are rarely plentiful.

Since a central purpose of the attachment immunity is to avoid commercialism, the exemption should not extend to lots held for speculation. ${ }^{117}$ Cemetery lots have a pronounced tendency to rise in price over a period of time as a result of two factors: additional improvements which enhance the appearance of the cemetery, and the constant depletion of available burial space with the corresponding increase in demand from those persons having relatives buried in the cemetery. In an attempt to exploit this commercial truth, unscrupulous promoters have promised huge profits on resale to encourage purchases of large quantities of lots for investment purposes. ${ }^{118}$ Many state legislatures have enacted statutes prohibiting

112 Ataska Comp. Laws Ann. \$36-5-7 (1949) ; Ariz. Rev. Stat. AnN. \$ 33-1122 (1956); Cal. HEalth \& SafeTy CODE \$8561; DeL. Code ANN. tit. 10, § 4902(a) (1953); D.C. Code ANN. \$27-111 (1951); Iowa Code ANN. \$627.6(5) (1950); Kan. Gen. Stat. Ann. \$ 17-1302 (1949); La. Rev. Stat. \$ 8:3 (1950); Me. Rev. Stat. Ann. ch. 58, \$\$ 6, 8, 20 (1954); MD. Ann. Code art. 23, \$164 (1957); Mass. Ann. Laws ch. 235, §34(11) (1956); Mich. Stat. Ann. \&5.3162 (1958); Mich. Stat. AnN. \& 27.1543 (Supp. 1959) ; MinN. Stat. ANN. §§ 306.14, 550.37(4) (1947); Mo. Ann. Stat. § 214.190 (1952); Mont. Rev. Codes ANN. \$§ 9-118, 93-5814 (1947); Neb. Rev. Stat. \$\$ 12-517, -520 (1954); Neb. Rev. Stat. § 25-1556 (1956); Nev. Rev. Stat. \$\$21.090, 83.110 (1959); N.J. Rev. Stat. \$ 8:2-27 (1937); N.Y. REAL Prop. Laws $\$ 450$ (except if no interments); OrLa. STat. ANN. tit. 31, $\$ \$ 1(3)$, 4 (First), tit. 8, \$7 (1951) ; S.D. Code \$ 11.1911 (1939); TENN. Code ANN. \$\$ 26-306, 46-102 (1955); VA. Code ANN. \$34-26 (1950); WASH. Rev. Code \$\$68.24.210, .220 (1951). (1947).

113 E.g., Iowa Code Anv. \$627.6(5) (1950); Mrnn. Stat. Ann. \$550.37(4)

114 E.g., Cat. Health \& Safety Code §8561; N.J. Rev. Stat. \$ 8:2-27 (1937). 115 However, this rule generally does not extend to lots held for speculation. See notes 117-21 infra and accompanying text.

110 N.Y. Real Prop. Laws \$450. See Empire Monument Co. v. Lewis, 252 App. Div. 301, 299 N.Y. Supp. 338 (1937), aff'd, 277 N.Y. 648, 14 N.E.2d 202 (1938).

117 This thesis has been stated by courts in several different contexts. See, e.g., Abell v. Proprietors of Green Mount Cemetery, 189 Md. 363, 56 A.2d 24 (1947) (rules and regulations); In re O'Neill's Will, 26 N.Y.S.2d 395 (Surr. Ct. 1941) (sale at public auction of cemetery lots which were estate's only assets); DuBois v. Fantinekill Cemetery Ass'n, 118 Misc. 37, 192 N.Y. Supp. 145 (Sup. Ct. 1921) (rule on divisibility); Memorial Gardens of the Valley, Inc. v. Love, 5 Utah 2d 270, 300 P.2d 628 (1956) (sale of securities).

118 See Blue v. United States, 138 F.2d 351 (6th Cir. 1943), cert. denied, 322 U.S. 736 (1944). Both of the national associations try to prevent their members from engaging in such tactics. See ACA CODE oF ETHICS para. 4, reprinted in Am. Cemetery Ass'n Bull., July 1959, p. 74. 
speculative activity. ${ }^{119}$ A few jurisdictions control speculation by allowing resale only if certain conditions are met, ${ }^{120}$ and one state has removed the attachment exemption in the case of speculators. ${ }^{121}$

\section{RIGHT OF BURIAL}

The most important single right of the owner of a cemetery lot is the right of burial. It is thus necessary to examine in some detail the rights of the various classes of potential owners of the lot. The original purchaser's right to determine who shall be buried in his lot ${ }^{122}$ is fettered only by the rules and regulations of the cemetery and by certain minimum standards of propriety ${ }^{123}$ - he may not, for example, bury a dog in a cemetery for humans. ${ }^{124}$ But having once permitted burial, he may not thereafter forbid the erection of a suitable monument by the relatives of the deceased. ${ }^{125}$ Of course, his permission to bury one person does not automatically give that person's spouse a right of burial as well. ${ }^{126}$

Upon the death of the original purchaser, his interest in the lot passes under any specific devise made in his will. ${ }^{127}$ Much litigation could be

119 Ariz. Rev. Stat. ANn. \$32-2162 (1956) (misdemeanor, sale void); CAL. Bus. \& Prof. Code § 9682 (misdemeanor); ConN. Gen. Stat. Rev. \$ 19-147 (Supp. 1959) (only new cemeteries prohibited); Fra. STAT. ANN. \&817.35 (Supp. 1959) (misdemeanor); IND. ANN. STAT. \$21-1024 (1950) (misdemeanor); IowA CODE AnN. \$ 566A.11 (Supp. 1960); ME. Rev. Stat. ANN. ch. 58, \$23 (1954) (misdemeanor, sale void); Mass. ANN. LAws ch. 114, §43B (1957) (sale void, fine or imprisonment or both); MONT. REv. CODES ANN. \$9-813 (1947) (mausoleumscolumbariums) (misdemeanor); ORE. REv. STAT. \$97.520 (Supp. 1959) ("except with the consent and approval of the Corporation Commissioner") ; R.I. GEN. LAws ANN. \$23-18-8 (1956) (fine or imprisonment or both); S.D. CODE \& 11.19A10 (Supp. 1960) (cannot represent as desirable speculative investment); UTAF CoDE ANN. $\$ 8-410$ (Supp. 1959) (misdemeanor); WASH. Rev. CoDE $\$ 68.24 .130$ (1951) (misdemeanor).

120 Ark. Stat. Ann. § 82-421 (a) (1960); Mp. Ann. Code art. 23, §164 (1957); N.J. REv. STAT. $\$ 8: 2-22$ (1937). Arkansas also withdraws its property tax exemption if lots are held for spectalative purposes. ARK. STAT. ANN. \$84-206 (third) (1960).

$121 \mathrm{Md}$. Ans. Cone art. 23, §164 (1957), Burdette v. Jackson, 179 Fed. 229 (4th Cir. 1910).

122 The rights of one who buys from the original purchaser are essentially the same as those of the first owner, except that the buyer may have a better chance of invalidating, on constitutional grounds, a racial restriction. See notes 75-78 supra and accompanying text. Additional reasonable restraints may be imposed by the seller.

123 Jackson, The LAW OF Cadavers 376-81 (2d ed. 1950).

124 See Hertle v. Riddell, 127 Ky. 623, 106 S.W. 282 (1907).

125 E.g., Sherman v. Gray, 150 Me. 13, 102 A.2d 867 (1954). The appropriate person is the surviving spouse, and not the executor. In the Matter of Estate of Clark, 5 Misc. 2d 259, 160 N.Y.S.2d 268 (Surr. Ct.), appeal dismissed by default, 3 App. Div. 2d 947, 163 N.Y.S.2d 391 (1957). However, there is no absolute right to have the names of all burials on a family monument, even if this means that no monument can be erected for those whose names do not appear on the family monument. See Fromer v. Shientag, 16 Misc. 2d 953, 189 N.Y.S.2d 937 (Sup. C. 1959). 126 In the Matter of Steiner, 179 Misc. 962, 43 N.Y.S.2d 556 (Sup. Ct. 1943); Cemetery Legal Compass, July 1941, p. 270.

127 E.g., IND. ANN. STAT. \$21-1008 (Supp. 1960 (if not specifically devised, lot becomes inalienable); Mass. ANN. LAws ch. 114, \$31 (1932); N.J. REv. Stat. \$ 8:2-21 (Supp. 1959). In some jurisdictions a lot may also pass under a written declaration filed in the office of the cemetery. E.g., CAL. HEALTH \& SAFETY CODE $\S 8603$. 
prevented if attorneys would add a clause to will forms to provide for such a devise. In the absence of a specific clause or statutory directive, it has generally been held that a cemetery lot will pass to the heirs-at-law and not to the beneficiary of a residual clause. ${ }^{128}$ The reasons most often advanced in support of this view are that institutions which have no use for the property-such as hospitals and colleges-may be named as residual legatees ${ }^{129}$ and that the courts' primary concern should be the protection of the familial interest in the lot: "It is . . . improbable that one has in mind a burial lot in a residuary devise. Men are not likely to inventory it among their assets or to regard it as property to be passed by a will. It is essentially a family heritage." 130

Many states have enacted statutes providing that a cemetery lot shall pass to the heirs unless specifically devised.131 A few of these statutes are quite specific in designating the classes of persons entitled to burial. ${ }^{132}$ In the absence of such a statute, courts have attempted to allocate the remaining spaces, ${ }^{133}$ usually by applying the general rule that as between equal owners priority is determined by order of death. ${ }^{134}$ If there are enough

128 McWhirter v. Newell, 200 I11. 583, 66 N.E. 345 (1903) ; McAndrew v. Quirk, 329 Mass. 423, 108 N.E.2d 667 (1952) (based on statute); Herb Estate, $70 \mathrm{~Pa}$. D. \& C. 598 (Orphans' Ct. 1950) (based on cemetery rule restricting burial to members of family); Petition of Waldron, 26 R.I. 84, 58 Atl. 453 (1904); Silva v. Helger, 75 R.I. 397, 67 A.2d 27 (1949) (dictum). Jackson supports this rule, JACKson, op. cit. supra note 123 , at $369-70$, as do other persons in the field. See Letter From James Worley, supra note 109; Letter From Raymond Louis Brennan, supra note 109; Letter From Martin Gaudian, supra note 111; Letter From Harry E. Sanders, secretary, Cemetery Ass'n of Pennsylvania, to Montefiore Cemetery Co., Philadelphia, Pa., Aug. 17, 1960. In such a case title passes directly to the heirs and is not subject to adminstration. In the Matter of Estate of Rosen, 173 Misc. 433, 17 N.Y.S.2d 794 (Surr. Ct. 1940) (based on statute); Cemetery Legal Compass, July 1940, p. 212; see note 131 infra. However, the executor may be specifically empowered to sell the lots. In re Wasserman's Estate, 101 N.Y.S.2d 974 (Surr. Ct. 1950), aff'd, 279 App. Div. 1062, 113 N.Y.S.2d 282 (1952).

129 Letter From James Worley, supra note 109: "There are too many cemetery plots belonging to too many schools, hospitals, and other institutions which have no use for them. The cemetery lot is part of the family institution and should be retained by the family." See also Herb Estate, supra note 128 (lot should not pass to stranger to the blood in view of cemetery rule restricting burial to members of family).

130 Petition of Waldron, 26 R.I. 84, 58 Atl. 453 (1904). See Letter From Raymond Louis Brennan, supra note 109: "The family plot is for the family and not for someone who may be the recipient of the worldly goods of the owner of the family plot"

131 Cal. Health \& Safety Code \$8603; Ind. AnN. Stat. \$21-1008 (Supp. 1960); Mass. ANn. Laws ch. 114, \$31 (1932); Minn. Stat. ANn. § 306.29 (1945); Mont. Rev. Codes ANN. \$9-821 (1947); N.J. Rev. Stat. \$ 8:2-21 (Supp. 1959) (repudiating Mohnkern v. Gennert, 136 N.J. Eq. 86, 40 A.2d 354 (Ch. 1945)) ; N.Y. MEMBERSHIP CoRp. LAWS \$ 84(6); ORE. REV. STAT. \$97.600 (1959); Pa. Stat. ANn. tit. 20, §180.14(15) (Supp. 1959); VT. Stat. tit. 15, ch. 182, \& 4088 (1947); Wash. Rev. Code \$ 68.32.040 (1951). Compare Nev. Rev. Stat. \$ 83.120 (1959); ORLA. STAT. ANN. tit. 8, \& 6 (1941); S.D. Code \$11.1905 (1939); WIS. STAT. \$157.10 (1957). See also Hammerstein v. Woodlawn Cemetery, 21 Misc. 2d 42,194 N.Y.S.2d 385 (Sup. Ct. 1960). Contra, MD. ANN. Code art. 23, § 164 (1957) (descends as real estate to heirs).

132 E.g., Minn. Stat. Ann. \$525.14 (1945); Mont. Rev. Codes ANN. \$\$9-829 to $-833(1947)$.

133 Axelrad v. Axelrad, 180 Misc. 418, 42 N.Y.S.2d 394 (Sup. Ct. 1943).

134 Silva v. Helger, 75 R.I. 397,67 A.2d 27 (1949). See also Ryan v. Schmit, 1 Wis. 2d 215, 83 N.W.2d 685 (1957); CAL. HEAITH \& SAFETY CoDE \$ 8651; IND. Ann. Stat. \$21-1008 (Supp. 1960); Cowan, Foresight Can Avert Many Costly Legal Entainglements, Am. Cemetery, Dec. 1959, pp. 21, 23. 
grave spaces available for all the co-owners, each has a vested interest in at least one grave space. ${ }^{135}$ A few states give the spouse of the decedent a vested right of burial if there is at least one burial space available..$^{136}$

When the lot has passed to the heirs there are significant limitations on their use of the lot. For example, the spouse of a co-owner may not be buried there over the objection of another co-owner of the lot ${ }^{137}$ - a rule analogous to the ancient real property doctrine of blood of the first purchaser. ${ }^{138}$ In various situations it has been held that, before a person may establish any rights in a cemetery lot, that person must bear a blood relationship to the original owner..$^{139}$ The continued vitality of this rule of blood is traceable in part to the survival in cemetery law of the principle of limited alienability. Statutes in many states render cemetery lots inalienable after the death of the original purchaser or after there has been an interment in the lot. ${ }^{140}$ Legislation also permits the purchaser to make the

135 Persinger v. Persinger, 39 Ohio Op. 315, 86 N.E.2d 335 (C.P. 1949). But where there are more than enough spaces the vested owners do not automatically split the rights in the remaining graves. Axelrad v. Axelrad, 180 Misc. 418, 42 N.Y.S.2d 394 (Sup. Ct. 1943) ; Petition of Waldron, 26 R.I. 84, 58 Atl. 453 (1904). In the only case in which the issue was raised, the court held a co-owner had no vested right to be buried in a particular grave space in the lot. Ryan v. Schmit, 1 Wis. $2 d$ 215,83 N.W.2d 685 (1957).

136 CaL. Health \& Safety Code $\$ \S 8601-02,8651$ (spouse, then parents and children of owner in order of death); CoNN. GEN. STAT. REv. \$19-158 (1958); IND. ANN. STAT. $\$ \$ 21-1007,-1008$ (Supp. 1960) (spouse, then parents and children in order of death) ; MAss. ANN. Laws ch. 114, $\$ \$ 29,32$ (wife), 33 (husband) (1932) ; MINN. Stat. ANN. \$ 525.14 (1945); Mont. REv. Codes ANN. $\$ \$ 9-819,-829$ to -833 (1947); N.Y. MEMberseip Corp. Laws § 88; Ore. Rev. Stat. \$97.570 (1959); Tex. Rev. CIV. STAT. art. 912a-12 (1953); Vr. Stat. tit. 15, ch. 182, \$ 4088 (1947); WAsH. Rev. Code $\$ 68.32 .020$ (1951). See also Cal. Healtr \& Safetx Code $\$ 8652$ (if no parent or child, spouse of child followed by heirs-at-law or spouses of heirs-at-law); Mo. REv. STAT. \$214.190 (1949). In many states, the spouse is also given control of the lot. See Hammerstein v. Woodlawn Cemetery, 21 Misc. 2d 42, 194 N.Y.S.2d 385 (Sup. Ct. 1960).

137 Friant v. Dolbow, 41 N.J. Super. 84, 124 A.2d 12 (Super. Ct. 1956). (third husband of first purchaser's wife not her blood relative). In any case involving the burial of one who does not have a vested interest, the agreement of all co-owners is a prerequisite to such burial. Silva v. Helger, 75 R.I. 397, 67 A.2d 27 (1949). Nor may another brother be buried when a lot has been conveyed to two brothers for the use of their immediate families. Axelrad v. Axelrad, 180 Misc. 418, 42 N.Y.S.2d 394 (Sup. Ct. 1943). Furthermore, heirs may exercise only the unused rights in the lot. Fromer v. Shientag, 16 Misc. 2d 953, 189 N.Y.S.2d 937 (Sup. Ct 1959). California provides a statutory exception to this rule. CAL. Healtr \& SafeTy Code $\S 8652$.

138 See Tiffany, Real Property \$1125 (3d ed. 1939).

139 Friant v. Dolbow, 41 N.J. Super. 84, 124 A.2d 12 (Super. Ct. 1956); In the Matter of the Estate of Appelbaum, 146 Misc. 603, 262 N.Y. Supp. 503 (Surr. Ct. 1933) (executors desired to sell mausoleum; decision based in part on New York alienability law); King v. Smith, 236 N.C. 170, 72 S.E.2d 425 (1952) (action for trespass); Herb Estate, 70 Pa. D. \& C. 598 (C.P. 1950) (lot does not pass to stranger to the blood in view of cemetery rule restricting burial to members of family). However, mere blood relationship is not sufficient to give title. Gibson v. Berry Cemetery Ass'n, 250 S.W.2d 600 (Tex. Civ. Ct. App. 1952).

140 CaL. Health \& SafETy Code $\$ 8650$ (after interment of member of family, relative, or lotowner); Ind. AnN. Stat. \$21-1008 (Supp. 1960); Mont. Rev. CoDes Ann. \$ 9-119 (1957) (after any interment, except may reconvey to cemetery); NEv. REv. STAT. $\$ 83.120$ (1959) (after any interment); N.J. REv. STAT. \$ 8:2-21 (Supp. 1959) (after any interment); N.Y. MEMrershIp CoRp. LAws $\$ \$ 84,86$ (after any interment); Orta. STAt. ANN. tit. $8, \S 6$ (1951) (while any burial remains); Ore. REv. STAT. $\$ 97.630$ (Supp. 1959) (after interment of member of family, relative, or lot- 
property inalienable prior to his death by filing appropriate papers with the cemetery company office. ${ }^{141}$ And to prevent relatives from splitting the lot and attempting to dispose of a part by claiming that only the portion containing burials is inalienable, other statutory provisions make cemetery lots indivisible. ${ }^{142}$ Limiting alienability has been viewed by writers ${ }^{143}$ as necessary and desirable:

There is every reason in logic and sentiment for destroying the alienability of a lot once a burial has been made therein . . . . It is abhorrent and shocking to the human sense that the one buried and the survivors should be denied the solace of burial together, or that those already interred should be interred among strangers. The person to whom title to the burial lot with its remaining graves may pass, if conveyed in the absence of statutory restriction, might permit any person, perhaps a stranger to the one already interred, to be buried therein. ${ }^{144}$

owner); S.D. CoDe $\$ 11.1905$ (1939) (while any burial remains); TEx. Rev. Crv. STAT. art. 912a-13 (1953); WASH. REV. CoDE \$ 68.32.060 (1951) (after interment of member of family, relative, or lotowner); WIS. STAT. \$157.10 (1957) (inalienable without consent of majority of board). See MinN. STAT. ANN. \$306.15 (Supp. 1959). See also Wolford v. Crystal Lake Cemetery Ass'n, 54 Minn. 440, 56 N.W. 56 (1893) (mortgage of cemetery land void); Hammerstein v. Woodlawn Cemetery, 21 Misc. 2d 42, 194 N.Y.S.2d 385 (Sup. Ct. 1960) (applying New York statute); In the Matter of the Estate of Appelbaum, 146 Misc. 603, 262 N.Y. Supp. 503 (Surr. Ct. 1933) (executors' right to sell mausoleum). Lots in which no one is buried do not come within the rules restraining alienation. Peebler v. Olds, $56 \mathrm{Cal}$. App. $2 \mathrm{~d}$ 8, 132 P.2d 233 (Dist. Ct. App. 1942) ; Billings v. Paine, 319 S.W.2d 653, 658-59 (Mo. 1959) (dictum). As to whether rights can be acquired in cemetery property by adverse possession, compare Locke v. Lester, 78 So. $2 \mathrm{~d} 14$ ( $\mathrm{La}$. Ct. App. 1955) (private land given over to public use as cemetery held imprescriptible and inalienable under statute forbidding prescription and alienation of public-use property), with Billings v. Paine, supra at 659-60 (dictum that right to specific, unoccupied lot may be acquired by adverse possession since no public right is affected).

141 Cal. Healte \& Safety Code $\$ 8680$; Ill. Ann. Stat. ch. 21, \$ 31 (SmithHurd 1951) ; Ind. ANn. Stat. \$\$21-229, -1009 (1950) ; La. Rev. Stat. Ann. § 8:2 (1951); Mass. Ann. Laws ch. 114, §28 (1957); Mont. Rev. Codes Ann. \$9-834 (1957); N.J. Rev. Stat. \& 8:2-23 (Supp. 1959); Wast. Rev. Code $\$ 68.32 .160$ (1951). 142 Cal. Healti \& Safety Code \$ 8571; ME. Rev. Stat. Ann. ch. 58, § 6 (1954) (if under one-half acre); N.J. Rev. Stat. \$ 8:2-20 (1939); ORE. Rev. Stat. \$ 97.550 (1959); TEx. REv. CIV. Stat. art. 912a-12 (1953); WASH. REv. CodE \$ 68.24.120 (1951). See also DuBois v. Fantinekill Cemetery Ass'n, 118 Misc. 37, 192 N.Y. Supp. 145 (Sup. Ct. 1922); Love v. Robinson, 219 Pa. 469, 68 Atl. 1033 (1908) (cemetery rule forbidding partition upheld).

143 "A cemetery lot should be inalienable once a burial has been made. This type of statute was first introduced in the State of New York and was an application to the cemetery lot of the spendthrift son trust principle. It is in line with the thinking that cemetery property should not be used for barter or trade, and should be conserved for the purpose of keeping the entire family together in death as in life." Letter From Raymond Louis Brennan, supra note 109. See Letter From Harry E. Sanders, supra note 128. Contra, Cowan, Involvement of Iegal Freedom, in 1959-1960 CEMETERY YEARBOOK 44, 48; Letter From James Worley, sitpra note 109; Letter From Martin Gaudian, supra note 111: "A burial plot is similar to any other interest in real estate. It is owned by a person or persons and he or they can authorize the burial of any person in such plot if said person comes within the category permitted by the Rules and Regulations of the cemetery." The NAC sponsors a lot exchange program whereby people moving to another part of the country may exchange cemetery lots in their old location for one near their present residence. 1957-1958 CEMrETERY YEARBOOK 82-83.

144 JACKSON, op. cit. supra note 123 , at 365 . 
This statement represents a point of view developed when the population was relatively immobile ${ }^{145}$ - most members of families remained for generations in the same town or city, or near the same rural cemetery. Under such circumstances it was both logical and natural for courts and legislatures to protect the family burying place for future members of that family. If one "black sheep" wished to dispose of the remaining graves in the family burial plot for his own benefit, ${ }^{146}$ a sense of outrage was justly felt. But today the mobility of the population has increased; since World War II, a large percentage of the American people has changed residence, not once, but several times. ${ }^{147}$ Children move to California, their elders to Florida. To continue an inflexible requirement that unused graves in family lots remain forever inalienable and indivisible ignores the realities of current conditions.

\section{ConcLusion}

From this examination of the rights of the purchaser of a cemetery lot, it is apparent that an intermixture of religion, sentiment, tradition, and real property law has created a unique form of property. Our legal system reflects this special quality in many respects, but much can still be done to clarify and improve relationships in this area of the law. Attorneys, by regularly inserting in wills specific devises of cemetery lots, would avoid the possibility of intrafamily squabbles. Where state statutes forbid speculation, or where there exists the risk of losing the lot under a state abandoned lot law, ${ }^{148}$ counsel may spare his client heavy losses by pointing out these restrictions upon property rights in cemetery lots. Through explanation of the cemetery's rules and regulations, the lawyer can prevent later misunderstandings by the lotowner concerning limits on types or sizes of monuments or the extent of permissible plantings.

State courts and legislatures have an obligation to provide adequate protection and treatment of this genus of property, consistent with its unusual nature. Some states have not passed even the most elementary laws in this area of vital public concern.

The purchaser of a burial lot also must be aware of the legal limitations upon his ownership rights. An informed buyer can be the difference between solace and aggravation for his family. The widespread ignorance of and indifference to this area of the law benefits neither society nor the individual.

R. S.

145 See Lerner, America as a Civilization 98 (1957).

146 Brennan suggests an analogy to a spendthrift trust. See note 143 supra.

147 U.S. Dep't of Commerce, Bureau of the Census, Historical Statistics of the United States ser. C 80-87, at 47 (1960).

148 See note 25 supra. 